\title{
O enigma do abismo bibliográfico: um convite [Sobre o percurso teórico-histórico do Seminário Internacional Arte da Bibliografia]
}

\section{Gustavo Silva Saldanha}

\begin{abstract}
Doutor em Ciência da Informação pelo Programa de Pós-Graduação em Ciência da Informação IBICT - UFRJ. Pesquisador Adjunto - IBICT. Professor Adjunto - Unirio.
\end{abstract}

http://dx.doi.org/10.1590/1981-5344/3245

O que tratamos por "arte da bibliografia" representa a história de um diálogo, um programa de reflexões compartilhadas entre distintos saberes, uma vivência teórica do Brasil para o mundo, do mundo para o Brasil. Iniciada em 2014, no Rio de Janeiro, com o 10 Seminário Internacional A ARTE DA BIBLIOGRAFIA, trata-se, antes, de uma procura epistemológica à beira de um certo abismo: afinal, o que é a Bibliografia?

Presente como conceito em distintas tradições de pensamento e de formação, personagem relevante do Helenismo, da Cristandade, do Humanismo italiano, do Renascimento, da Reforma e da Contrarreforma, da Revolução científica e da Revolução Francesa, projeto de "salvação do mundo" pela via do pacifismo no final do século XIX, a história de um nome transforma-se nas visões de Giulia Crippa, André Araújo e Gustavo Saldanha, desde então, em um enigma e, ao mesmo tempo, uma grande marcha meta-epistêmica: o acontecimento oculto que se revela na própria espiral que a inscreve.

Quando enunciamos a palavra "bibliografia" estamos tratando dos saberes da linguagem, do livro, da escrita, do documento, da informação, do texto, da obra, do discurso, da classificação, do autor, do leitor, ou, ainda, da representação? Qual ciência funda, qual ciência abarca, qual fundamento epistemológico subjaz da reflexão sobre o "bibliografar"? Nenhuma das respostas cabem em um só enunciado. Todas as possibilidades abertas pelas questões são trilhas percorridas pela marcha intitulada A Arte da Bibliografia.

Jean Meyriat (1993, p. 548-549) recorre ao grego tardio para se reportar à designação de "bibliografia", fruto de uma "doutrina progressivamente consolidada", tomada como a própria escrita ou a 
transcrição dos livros. O abismo já está dado aqui: um espelho que reflete seu reflexo e nada mais de cena alguma ...um espelho que "nada diz do que já foi dito", diria Foucault (2002, p. 9), em sua inquietação com o mise en abyme de Velázquez em As Meninas. Arte antiga, fundamentalmente helenista, filha de um tempo em que dizer e representar se tornam dois elementos centrais para a reflexão filosófica. Em poucas palavras, o discurso de Meyriat percorre Antiguidade, Medievo e Modernidade: a bibliografia segue seu transcurso da Antiguidade à informática na Contemporaneidade. Mas "tudo isso" é Bibliografia?

Do diálogo sobre o abismo da questão nasce o programa: estudar a Bibliografia. E não o fazer de modo solitário, no risco "luxuoso" do silêncio dos livros fechados: convocar todos os artífices de tal fazer e de tal pensar. Dialogar ainda mais. E não tecer tal trama de inquietações só no Brasil. Abrir as janelas para atores e atrizes no contexto internacional que lutam pelo conceito, que atuam em suas fronteiras intersubjetivas, que já estiveram ou estão nos polos mais concretos de seus acontecimentos no espaço-tempo.

No percurso, de 2014 até a presente data, aquilo que se tornou o Seminário Internacional A ARTE DA BIBLIOGRAFIA ganhou literalmente o mundo: citado na Bélgica, no desdobramento em Mors do antigo Instituto Internacional de Bibliografia, o programa não deixou de avançar na direção do e junto ao enigma, no horizonte brumado, passando duas vezes pela prosa com a Itália, no contato com um dos mais importantes bibliógrafos do mundo, Alfredo Serrai. E mergulhou no abismo que a bibliografia instaura desde a sua primeira enunciação.

O evento colocou em diálogo (e "em abismo") instituições brasileiras como IBICT, UNIRIO, UFRJ, USP, UNB, UFMG, dentre outras, sempre à procura, não da definição e da demarcação sumárias, mas das metaabordagens bibliográficas. O resultado até o momento das inquietações foi publicado nas revistas científicas Informação \& Informação (UEL) e InCID (USP), respetivamente, em 2015 e em 2016, encontrando agora, a partir das relações com o pensamento de Cristina Dotta Ortega e Dina Araújo, na revista Perspectivas em Ciência da Informação (UFMG), sua nova morada provisória. Os atuais questionamentos, colocam, pois, em prosa aberta, os grupos de pesquisa "Bibliotheca Disciplinata", de Giulia Crippa, "Ecce Liber", de Gustavo Saldanha, e "Fundamentos Teóricos, Metodológicos e Históricos da Organização da Informação", de Cristina Ortega, coletivos que discutem a bibliografia em suas mais diferentes manifestações.

Como lembra Meyriat (1993), podemos pensar a bibliografia como um véritable mise en abyme, enunciado na teoria otletiana do Traité (OTLET, 1934) desde a folha de rosto de sua grande obra: le livre sur le livre. Trata-se de um enigma que nos convida saltar em um universo de redes de abordagens teóricas e aplicadas (expressões também presentes na folha de rosto do Traité) que se colocam dentro de outras abordagens aplicadas e teóricas, constituindo um universo na qual o homem, segundo a profecia mallarmaica, jamais escapará: tudo restará dentro de um livro, este que, por sua vez, já está dentro dele, do livro. Os confins de uma 
arte da bibliografia estão abertos, pois a arte bibliográfica está sempre se repensando a partir do próprio texto que a transcreve. Afinal, o que é a Bibliografia? A pergunta já é, ela própria, bibliográfica. Aqui e alhures.

\section{Referências}

FOUCAULT, M. As Palavras e as coisas: uma arqueologia das ciências humanas. São Paulo: Martins Fontes, 2002.

MEYRIAT, Jean. La bibliographie. In.: ESTIVALS, Robert. Les sciences de l'écrit. PARIS: AIB, 1993. p. 548-549

OTLET, Paul. Traité de documenatation: le livre sur le livre: théorie et pratique. Bruxelas: Editiones Mundaneum, 1934. 